\title{
RELATIONSHIP BETWEEN THE STAINING PROPERTY OF MAST CELL GRANULE WITH ALCIAN BLUE-SAFRANIN O AND TOLUIDINE BLUE O, AND THE CONTENT OF MAST CELL PROTEASE I IN THE GRANULE OF RAT PERITONEAL MAST CELL
}

\author{
OSAmu KORETOU \\ Department of Pathology, Shiga University of Medical Science, Tsukinowa-cho, \\ Seta, Otsu, Shiga 520-21
}

Received for publication August 8, 1987 and in revised form November 9, 1987

\begin{abstract}
The relationship between the amount of rat mast cell protease I (RMCP I) in the granules and the stainability of granules was examined using the peritoneal mast cell of the Sprague-Dawley rat (6 weeks old). Epon sections of rat peritoneal mast cells were stained immunohistochemically for RMCP I, and observed with an electron microscope. Consecutive sequential light microscopic sections were stained with toluidine blue $O$. Photographs of electron microscopy and light microscopy of the same mast cells were compared each other. The dark violet granules with toluidine blue $O$ contained the largest amount of RMCP I, the purple or intermediately stained granules less amount of RMCP I, and the pink granules slight amount of RMCP I. The mast cells, which were fixed with glutaraldehyde and osmium tetroxide and stained with alcian blue-safranin, followed by epon embedding, showed various colors of granules, if roughly divided, safranin positive, intermediately stained, and alcian blue positive granules. These sections were further stained with toluidine blue $O$ and it was found that the safranin positive, the intermediately stained and the alcian blue positive granules with alcian blue-safranin double staining corresponded to the dark violet, purple and pink granules with the toluidine blue $O$ staining, respectively. Thus it was concluded that light microscopic observations by toluidine blue $O$ staining and/or alcian blue-safranin $O$ double staining which is more generally accepted in regard to the distinction of mast cell granules than toluidine blue $O$ staining enabled us to estimate the amount of RMCP I in the mast cell granules. This result will be useful to interpret the functional activity of mast cell populations in various physiological and pathological conditions.
\end{abstract}

Mast cell granules contain histamine, serotonin, heparin and proteins (1). The role of histamine and/or serotonin in the immunological responses and in the early phase of acute inflammation is reasonably well elucidated. Rat mast cell protease I (RMCP I), a potential functional protein of the granules in the connective tissue mast cells, is not well understood in regard to its role in the physiological or pathological conditions, although its enzymatic activity to the intercellular matrix is well demonstrated in the in vitro examinations $(9,14)$. The RMCP I has been well localized to the granules immunohistochemically both with light and electron microscopy, and the difference in enzyme content of each granule has been demonstrated (un- 
published data). So it will be possible to relate the enzyme content and therefore the functional activity of mast cells with physiological and pathological conditions. However, the immunohistochemical methods are complex and it is difficult, if not possible, to apply these methodologies to the examinations of the vast majority of physiological and pathological conditions, in which extensive and chronological examinations are required. The author tried to find techniques which could enable us to examine more precisely and reasonably the content of RMCP I of mast cell granules in the various conditions. Alcian blue-safranin double staining method is a well established method $(2,3,6,7)$ and the author examined the relationship between the stainability of the granules of connective tissue mast cells and the RMCP I content of granules expressed by the electron immunohistochemical method.

\section{MATERIALS AND METHODS}

I. Tissue preparation.

Male Sprague-Dawley rats of 6 weeks of age were used. Rats were killed by exsanguination under ether anesthesia. Immediately after the death of animal, the fixative, $1 \mathrm{ml}$ per $10 \mathrm{~g}$ body weight, was injected into the peritoneal cavity. The fixative used was $2 \%$ glutaraldehyde in $0.1 \mathrm{M}$ sodium phosphate buffer, $\mathrm{pH}$ 7.3. After gentle massage on the abdomen for $90 \mathrm{sec}$, the peritoneal cavity was opened and the fixative containing peritoneal cells was collected in a glass tube and kept in a refrigerator for one hr. The fixed peritoneal cells were washed 3 times with $0.1 \mathrm{M}$ sodium phosphate buffer, $\mathrm{pH} 7.3$ for $90 \mathrm{~min}$ by repeated centrifugation and resuspension and were collected as pellets. The pellets were subsequently fixed with $1 \%$ osmium tetroxide. One half of the fixed specimen was embedded in epon. The other half was stained with alcian blue and safranin as described below and embedded in epon.

II. Histochemical staining.

(a) Toluidine blue $\mathrm{O}$ staining.

One micron sections of epon embedded peritoneal cells were immersed for $5 \mathrm{~min}$ in $0.05 \%$ toluidine blue which was dissolved in $0.01 \mathrm{M}$ acetate buffer, $\mathrm{pH} 4.0$ and rinsed in distilled water, dried and were used for the observation.

(b) Alcian blue-safranin $\mathrm{O}$ staining. follows:

The procedure for alcian blue-safranin staining before epon embedding was as

1. After osmium fixation, the pellets were washed with distilled water,

2. immersed in $3 \%$ acetic acid,

3. stained with $1 \%$ alcian blue 8 GX (C.I. 74240, J. T. Baker Chemical Co.) in 3\% acetic acid for $2 \mathrm{hr}$,

4. washed with $3 \%$ acetic acid for $5 \mathrm{~min}$,

5. stained with $0.5 \%$ safranin $\mathrm{O}$ in $0.1 \mathrm{~N} \mathrm{HCl}$ for $10 \mathrm{~min}$,

6. dehydrated with ethanol and embedded in epon 812 .

III. Purification of RMCP I and preparation of anti-RMCP I serum.

Purification of RMCP I and preparation of anti-RMCP I serum were performed by the same method reported previously (4).

IV. Electron immunohistochemical staining for RMCP I.

Ultrathin section of epon embedded peritoneal cells was stained by indirect immunohistochemical method as follows: 
1. The section was immersed in $10 \% \mathrm{H}_{2} \mathrm{O}_{2}$ for $10 \mathrm{~min}$,

2. washed with distilled water 3 times, $15 \mathrm{~min}$ in total,

3. immersed in normal goat serum for $10 \mathrm{~min}$,

4. immersed in anti-RMCP I rabbit serum for $2 \mathrm{hr}$,

5. washed with phosphate buffered saline 3 times, $30 \mathrm{~min}$ in total,

6. immersed in horseradish peroxidase labelled anti-rabbit IgG goat serum for

$30 \mathrm{~min}$,

7. washed with phosphate buffered saline 3 times, $30 \mathrm{~min}$ in total,

8. reacted with $3,3^{\prime}$-diaminobenzidine- $\mathrm{H}_{2} \mathrm{O}_{2}$ solution for $5 \mathrm{~min}$,

9. washed with distilled water 3 times, $15 \mathrm{~min}$ in total,

10. immersed in $2 \%$ osmium tetroxide for $30 \mathrm{~min}$,

11. washed with distilled water 3 times, $15 \mathrm{~min}$ in total,

12. observed and photographed with Hitachi H-700 electron microscope.

Control section for immunohistochemical staining was treated with preimmune rabbit serum instead of anti-RMCP I serum and, after immunohistochemical staining, stained with uranyl acetate.

\section{RESULTS}

I. Toluidine blue $\mathrm{O}$ staining.

Rat peritoneal mast cell granules were stained purple with toluidine blue $O$. They were not stained into the same color, but stained into various colors, namely, dark violet granule, purple granule and pink granule (Fig. 1a). However, purple granules showed various shades of purple from nearly dark violet to nearly pink, indicating the continuous staining pattern of granules from dark violet, through purple to pink. Dark violet granules were generally smaller than pink granules. Purple granules were middle in size between dark violet granules and pink granules.

II. The relationship between the stainability of the granule with toluidine blue $\mathrm{O}$ and the amount of RMCP I.

The localization of RMCP I in the mast cells was examined from the immunoreaction product of RMCP I on the epon embedded sections based on the indirect electron immunoperoxidase method.

Consecutive sections for immunohistochemical electron microscopy and toluidine blue light microscopy were obtained from the epon block. An electron micrograph of one mast cell was compared with the consecutive light micrograph of the same mast cell and the relationship between the amount of RMCP I of a given granule and the stainability with toluidine blue of the same granule was examined.

The dark violet granules contained a large amount of RMCP I, the granules of intermediate color a lesser amount of RMCP I, and the pink granules a slight amount or none of RMCP I (Figs. 1a, 1b). Therefore, the RMCP I content in mast cell granule is reflected in the shade of color from dark violet to pink with toluidine blue $\mathrm{O}$ staining. A few granules, less than $2 \%$, did not show the relationship described above, because some granules in the section for light microscopy were not present in the next consecutive section for electron microscopy.

Control section for immunohistochemistry revealed that mast cell granules show negative immuno-reaction product and, though the section was stained with uranyl acetate, there was a clear difference in electron density of granules as compared with 

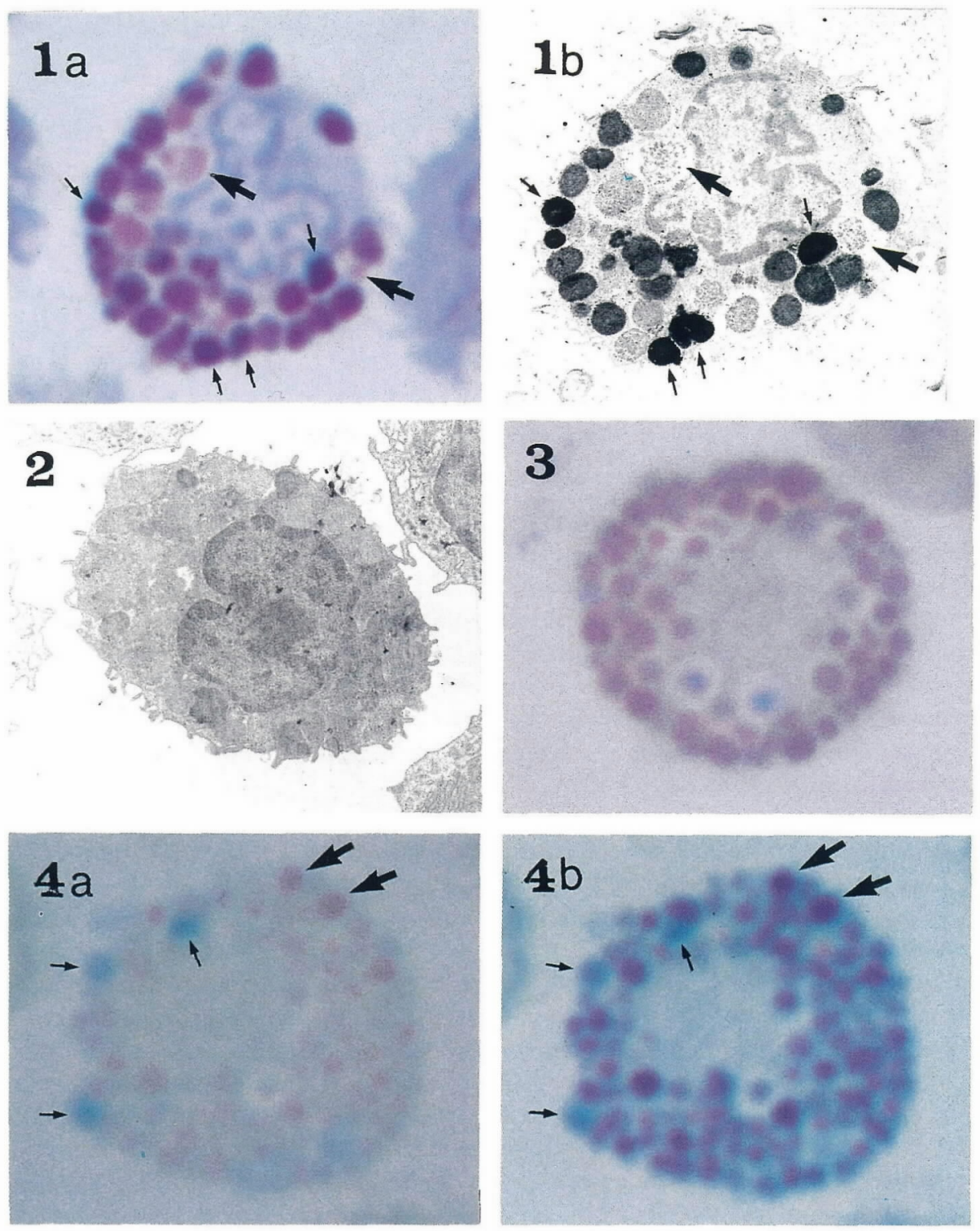
the granule in Fig. 1b (Fig. 2).

III. Alcian blue-safranin $\mathrm{O}$ staining.

Rat peritoneal mast cell granules have been classified into alcian blue positive granules and safranin positive granules. However, it became clear from the present study that, in addition to these granules, mast cells also contained granules that were stained in an intermediate color between both granules (Fig. 3). Thus, mast cell granules show the same continuous change of color with alcian blue-safranin as with toluidine blue $\mathrm{O}$.

IV. Comparison of alcian blue-safranin $\mathrm{O}$ double staining with toluidine blue $\mathrm{O}$ staining on the granules in mast cells.

The fixed specimens after alcian blue-safranin $O$ double staining were embedded in epon and the thin section was again stained with toluidine blue $O$. The same mast cell was photographed before and after toluidine blue $\mathrm{O}$ staining. Thus, the color of the same granule in the given mast cell could be compared between that stained with alcian blue-safranin $\mathrm{O}$ and that with toluidine blue $\mathrm{O}$.

The safranin positive granules and the intermediate granules stained with alcian blue-safranin $\mathrm{O}$ were changed to dark violet granule and purple granule with toluidine blue $\mathrm{O}$ staining, respectively. However, the alcian blue positive granules remained light blue with the staining by toluidine blue $\mathrm{O}$ (Figs. 4a, 4b). Therefore, mast cell granules that are stained a darker shade of purple with toluidine blue $\mathrm{O}$ are more safraninophilic.

\section{DISCUSSION}

When peritoneal mast cells are treated with histamine liberators, such as com-

FIgs. 1a, b. Consecutive sections were obtained from the epon block. One section was stained with toluidine blue (Fig. 1a) and another section was localized for RMCP I by indirect immunoperoxidase method (Fig. 1b). Mast cell granules are stained into various colors with toluidine blue, namely, dark violet granules, purple granules and pink granules. However, these granules show the continuous staining pattern from dark violet through purple to pink (Fig. 1a). The amount of RMCP I vary with mast cell granules (Fig. 1b).

In comparison with the same mast cell on consecutive sections, the dark violet granules contain a large amount of RMCP I (small arrow), the granules of intermediate color a lesser amount of RMCP I, and the pink granules a small amount or none of RMCP I (large arrow).

FIG. 2. Mast cell on control section for immunohistochemistry shows negative immuno-reaction product in granules. Though the section was stained with uranyl acetate, mast cell granules show a clear difference in electron density as compared with the granule containing a large amount of RMCP I in Fig. 1b (Fig. 2).

FIG. 3. Mast cell stained with alcian blue-safranin contains alcian blue positive granules and safranin positive granules and, in addition to these granules, also contains granules that are stained in intermediate color between both granules. Thus, mast cell granules stained with alcian bluesafranin show the same continuous staining pattern as mast cell granules stained with toluidine blue.

FIG. 4a. Alcian blue-safranin stained mast cell (before toluidine blue staining) contains a small number of red granule (large arrow) and a small number of blue granule (small arrow).

FIG. 4b. Alcian blue-safranin stained mast cell (after toluidine blue staining).

The same mast cell in which the same section in Fig. 4 a was again stained with toluidine blue. In comparison with Fig. 4a, blue granules remain blue (small arrow) and red granules change into dark violet (large arrow), and other granules change into purple with toluidine blue. 
pound $48 / 80$, the mast cell granules show swelling and lowering of electron density (8, 11). Treatment of sensitized mast cells with $\operatorname{IgE}$ results in similar morphological changes $(1,5)$. These morphological changes lead to discharge of pharmacologically active substances, such as histamine or serotonin.

However, there are similar morphological changes of granules, which are not related to histamine liberators or immunological response. For example, Takeoka $e t$ al. reported a morphological difference of granules within one and the same mast cell in the snout of normal rats (12). Later he reported a sequential alteration of mast cell granules from electron-optically compact granules through fine reticular granules to almost empty granular sacs in the regenerating mast cell population of rat ascitic fluid. Though this phenomenon is prominent in the regenerating ascitic mast cells, it is also found in a lesser degree in the normal untreated rats (13). These less dense granules of normal rat ascitic mast cells are prominent in young rats and decrease with age (unpublished data).

In the regenerating mast cells the sequential ultrastructural alterations are intimately related with acid phosphatase reaction of the granules (13). The acid phosphatase reaction is not found in the compact granules, intensive in the reticular granules and less prominent with the decrease of electron density of granules. In his report Takeoka suggested that this phenomenon is a physiological process of secretion of the content of mast cell granules. However, he did not describe what kind of substances were secreted.

The mast cell granules contain histamine, serotonin, heparin and proteins. That histamine and serotonin are pharmacologically active substances is well known. The role of heparin is the subject of controversy. The proteins which give the granules an electron opacity are the subject of great interest at present. Among the proteins, the rat mast cell protease I (RMCP I) is the largest in amount (10). It is suspected that the ultrastructural alteration reported by Takeoka $(12,13)$ in the granule content would be largely related to the change of amount of RMCP I in the granules.

As described above, the immunohistochemical electron microscopy localized the RMCP I on the mast cell granules. However, the electron microscopic immunohistochemistry is a rather troublesome method. If we could estimate the amount of RMCP I by the conventional staining method, it would be very convenient to study the function of mast cells in regard to enzymatic activity. Thus, the relationship between the stainability of granules with toluidine blue and the amount of RMCP I was examined.

In the study with serial sections for electron microscopic and light microscopic examination it was clarified that the dark violet granules of toluidine blue stained section correspond to the electron dense granules with a large amount of RMCP I. The granules of intermediate color correspond to the granules of less amount of RMCP I and the pink granules correspond to the reticular granules with a slight amount or none of RMCP I.

Alcian blue-safranin double staining has been generally accepted in regard to the distinction of granule in mast cells. Many reports about mast cells stained with alcian blue-safranin have been published. However, the difference in stainability of granules with alcian blue and safranin is not fully clarified. The author tried to apply the immunohistochemical procedure on the alcian blue-safranin stained and epon embedded section. This method with glutaraldehyde-osmium fixation and staining 
with alcian blue-safranin prior to epon embedding is a well established method in our laboratory, and the color of specimen is stable, compared with toluidine blue staining.

However, the thin section from this epon block could not be stained with the immunohistochemical method for electron microscopy. So the author tried to compare both staining methods with regard to granule stainability. The results showed that the safranin positive granules correspond to dark violet granules and alcian blue positive granules to the purple or pink granules.

Thus the alcian blue positive granules contain a small amount or none of RMCP I and the safranin positive granules contain a large amount of RMCP I. Recently, Miyashita $e t$ al. showed that the alcian blue positive granules correspond to the reticular granules with positive acid phosphatase reaction and the safranin positive granules correspond to the compact granules with negative acid phosphatase reaction (7). With these results the secretion of granular content suggested by Takeoka (12, 13) can be related to the secretion of RMCP I.

Although this result was obtained from peritoneal mast cells of 6 weeks old rats, it would be applicable to connective tissue type mast cells which contain the same substances in their granules as peritoneal mast cells.

The data of the previous workers can be interpreted with regard to the RMCP I content. Combs reported that mast cells of rat embryo contain alcian blue positive granules and in the course of development the safranin positive granules increased in number (2). Matsui reported that the regenerating rat peritoneal mast cells contained alcian blue positive granules in the early phase of regeneration and later these granules were gradually replaced with safranin positive granules (6). These results are interpreted on the base of the observations of the present author as follows: The mast cells contain in the early phase of development or in the early phase of the regeneration none or a small amount of RMCP I and later the amount of RMCP I increases in the course of embryonic development or regeneration. And, on the basis of Takeoka's hypothesis $(12,13)$, the secretion of RMCP I in these mast cells is active in the early phase and decreases with time.

The role of RMCP I or rat mast cell chymase is not clear at present, especially in the pathological conditions not related to the immunological responses. The RMCP I digests components of intercellular matrix, especially type IV collagen (9) and fibronectin (14) in vitro. Since both of these matrix proteins participate in cell-cell and cell-matrix adherence, the degradation of these extracellular matrix may play roles in certain physiological and pathological conditions in which cells migrate or invade. Here we can assume the role of mast cells especially in regard to their perivascular position in the physiological conditions or to their appearance in the foci of wound healing or in the chronic inflammatory lesions. The mast cells with their enzymatic activity might help the reactive cells migrate into the foci through the dissolution of intercellular matrix.

The sequential alterations of regnerating ascitic mast cells in the alcian bluesafranin double staining described by Matsui (6) or in the ultrastructural alteration coupled with the acid phosphatase reaction described by Takeoka (13) may reflect the role of mast cells in maintenance of fluidity of the ascitic fluid.

The mucosal mast cells contain only alcian blue positive granules, yet these granules have a high electron opacity and also they contain RMCP II (15). Therefore the alcian blue positive granules of rat connective tissue mast cells of the present study 
might contain RMCP II. This possibility is now under the investigation.

\section{ACKNOWLEDGEMENTS}

The author thanks Professor Osamu Takeoka, Department of Pathology, Shiga University of Medical Science, for his helpful suggestions and encouragement and reading of the manuscript.

\section{REFERENCES}

1. Anderson, P., Slorach, S. A. and Uvnäs, B.: Sequential exocytosis of storage granules during antigen-induced histamine release from sensitized rat mast cells in vitro. An electron microscopic study. Acta Physiol. Scand. 88; 359-372, 1973.

2. Combs, J. W., Lagunoff, D. and Benditt, E. P.: Differentiation and proliferation of embryonic mast cells of the rat. J. Cell Biol. 25; 577-592, 1965.

3. Hidaka, T.: Histochemical and ultrastructural studies on the discharge of granules of rat peritoneal mast cells. J. Kyoto Pref. Univ. Med. 87; 1139-1156, 1978 (in Japanese).

4. Koretou, O.: Purification of rat skin protease and its relationship to mast cell granules. $J$. Shiga Univ. Med. Sci. 1; 59-66, 1986 (in Japanese).

5. Lawson, D., Fewtrell, C., Gomperts, B. and Raff, M. C.: Anti-immunoglobulin-induced histamine secretion by rat peritoneal mast cells studied by immunoferritin electron microscopy. J. Exp. Med. 142; 391-402, 1975.

6. Matsui, S.: Histochemical studies on regenerating mast cells in rat ascitic fluid. J. Kyoto Pref. Univ. Med. 85; 483-492, 1976 (in Japanese).

7. Miyashita, S., Koretou, O., Iwai, Y., Arizono, N. and Takeoka, O.: Acid phosphatase reaction and alcian blue-safranin staining of rat peritoneal mast cells. Acta histochem. cytochem. 19; 761-765, 1986.

8. Röhlich, P., Anderson, P. and Uvnäs, B.: Electron microscope observations on compound 48/80-induced degranulation in rat mast cells. Evidence for sequential exocytosis of storage granules. J. Cell Biol. 51; 465-483, 1971.

9. Sage, H., Woodbury, R. G. and Bornstein, P.: Structural studies on human type IV collagen. J. Biol. Chem. 254; 9893-9900, 1979.

10. Schwartz, L. B. and Austen, K. F.: Acid hydrolases and other enzymes of rat and human mast cell secretory granules. In Biochemistry of the Acute Allergic Reactions, ed. by E. L. Becker, A. S. Simon and K. F. Austen, Alan R. Liss, Inc., New York, 1981, p. 103-121.

11. Singleton, E. M. and Clark, S. C. Jr.: The response of mast cells to compound 48/80 studied with the electron microscope. Lab. Invest. 14; 1744-1763, 1965.

12. Takeoka, O., Yamashita, S., Tada, N., Matsui, S. and Masu, S.: Finer structures of the mast cells of rat. J. Kyoto Pref. Univ. Med. 75; 1220-1224, 1966.

13. Takeoka, O.: Secretion of the content of granules and its relationship to the acid phosphatase reaction in regenerating rat peritoneal mast cells. Acta histochem. cytochem. 7; 231-238, 1974.

14. Vartio, T., Seppä, H. and Vaheri, A.: Susceptibility of soluble and matrix fibronectins to degradation by tissue proteinases, mast cell chymase and cathepsin G. J. Biol. Chem. 256; 471$477,1981$.

15. Woodbury, R. G. and Neurath, H.: Purification of an atypical mast cell protease and its levels in developing rats. Biochemistry 17: 4298-4304, 1978. 